\title{
Sertoli cell tumor and gonadoblastoma in an untreated 29-year-old 46,XY phenotypic male with Frasier syndrome carrying a WT1 IVS9+4C>T mutation
}

\author{
Sophia Kitsiou-Tzeli*, ${ }^{1}$ Maria Deligiorgi*, ${ }^{2}$ Sophia Malaktari-Skarantavou, ${ }^{2}$ \\ Charalampos Vlachopoulos, ${ }^{3}$ Spyridon Megremis, ${ }^{1}$ Irene Fylaktou, ${ }^{1}$ \\ Joanne Traeger-Synodinos, ${ }^{1}$ Christina Kanaka-Gantenbein, ${ }^{4}$ \\ Christodoulos Stefanadis, ${ }^{3}$ Emmanuel Kanavakis ${ }^{1}$
}

${ }^{1}$ Department of Medical Genetics, Medical School, University of Athens, Aghia Sophia Children's Hospital, ${ }^{2}$ Department of Endocrinology and Metabolism, Hippokration General Hospital of Athens, ${ }^{3} 1$ st Department of Cardiology, Medical School, University of Athens, Hippokration Hospital, ${ }^{4}$ Division of Endocrinology, Diabetes and Metabolism, First Department of Pediatrics, Medical School, University of Athens, Aghia Sophia Children's Hospital, Athens, Greece

*These authors contributed equally

\begin{abstract}
OBJECTIVE: Frasier syndrome (FS) phenotype in 46,XY patients usually consists of female external genitalia, gonadal dysgenesis, high risk of gonadoblastoma and the development of end stage renal failure usually in the second decade of life. FS is caused by heterozygous de novo intronic splice site mutations of the Wilms' tumor suppressor gene 1 (WT1), although a few cases with typical exonic $W T 1$ Denys-Drash mutations that resemble an FS phenotype have been described. The aim of this study was to present further data on the spectrum of FS phenotypes through the evaluation of a 29-year-old patient with a predominantly male phenotype and coexistence of Sertoli cell tumor and gonadoblastoma. RESULTS: Genetic analysis using standard methods for DNA sequencing confirmed FS due to a $W T 1$ gene mutation, IVS9+4C $>$ T. CONCLUSIONS: This very rare case illustrates the natural course of FS over many years due to the neglect by the patient to address his need for follow-up, while adding further data on the spectrum of FS phenotypes associated with IVS9+4 C $>$ T mutations. The coexistence of the rare Sertoli cell tumor and gonadoblastoma emphasizes that early clinical recognition and molecular identification facilitates appropriate patient management, especially with respect to the high risk of gonadal malignancy.
\end{abstract}

Key words: Frasier syndrome, Sertoli cell tumor, Gonadoblastoma, WT1 gene 


\section{INTRODUCTION}

Frasier syndrome (FS) was first described in 46,XY monozygotic twins in $1964 .{ }^{1}$ The FS phenotype in $46, X Y$ patients usually consists of female external genitalia, gonadal dysgenesis, high risk of gonadoblastoma and development of end stage renal failure usually in the second decade of life. FS is caused by heterozygous de novo intronic splice site mutations in the Wilms' tumor suppressor gene 1 (WT1), although a few cases with typical exonic WT1 Denys-Drash mutations that resemble an FS phenotype have been described. ${ }^{2-4}$ Denys-Drash syndrome (DDS) is a rare disorder affecting urogenital development and characterized by the triad of early onset nephrotic syndrome, disorders of sex differentiation and predisposition to Wilms' tumor. FS and DDS have similarities as well as clinical and genetic differences. In DDS, the onset of nephropathy due to diffuse messangial sclerosis presents in infancy and progresses to end stage renal failure usually before the age of 5 years. In FS, nephropathy due to focal segmental glomerulosclerosis occurs in childhood and progresses to end stage renal failure during the second or third decade of life. In DDS, there is a high risk of Wilms' tumor, whereas in FS the major risk of malignancy is the development of gonadoblastoma. The most frequent WT1 defects in DDS are missence mutations located in exons 8-9, while FS is predominantly caused by mutations in the donor splice site in intron 9 of the WT1 gene.,

The $W T 1$ gene is located on chromosome 11p13 and consists of 10 exons that include a zinc finger DNA binding domain. The gene is expressed in a wide variety of embryonic tissues including the mesenchymal cells of the foetal kidney and the stromal cells of the gonads and the spleen. ${ }^{6}$ WT1 acts as a transcriptional activator or repressor depending on the cellular or chromosomal context. ${ }^{7,8}$ It has four major isoforms, due to the insertion of three amino acids (lysine/threonine/serine, KTS) between zinc fingers 3 and 4 and the insertion of an alternatively spliced 17 amino acid segment encoded by exon 5 , resulting from alternative splicing of the pre-mRNA. ${ }^{9}$ FS mutations in intron 9 of the WT1 gene lead to a change in splicing that results in deficiency of the usually more abundant KTS-positive isoforms and reversal of the normal KTS-positive to negative ratio from 2:1 to 1:2, a balance that is necessary for WT1 normal function. ${ }^{10,11}$
We report here a 29-year-old patient with a predominantly male phenotype and coexistence of Sertoli cell tumor and gonadoblastoma. Genetic analysis confirmed Frasier syndrome due to a $W T 1$ gene mutation, IVS9+4C $>\mathrm{T}$.

\section{MATERIAL, METHODS AND RESULTS}

\section{Case Report}

The patient, a 29-year-old male, is the only child of non-consanguineous Greek parents. His father was deaf due to a childhood infection and his mother has congenital deafness of unknown origin but is otherwise healthy. At birth, the patient presented with bilateral cryptorchidism, scrotal hypospadias and persistent Mullerian ducts. His karyotype was 46,XY. At the age of 2 years, he underwent orchidopexy on the left side, whereas on the right side the surgeon reported that no testis was found. Later, a surgical repair of hypospadias was undertaken. At the age of 8 years, he underwent removal of the Mullerian structures. During childhood, he experienced several episodes of urinary tract infections due to a diverticulum of the urethra. There was no medical follow-up from age 11 until 29 years, probably because the family wanted to forget the stress provoked by the multiple surgical procedures during early childhood. The patient reported being asymptomatic during this period.

At the age of 29 years he was admitted to the hospital because of severe hypertension (220/100 $\mathrm{mmHg}$ ) and blurred vision. A complete ophthalmological evaluation demonstrated normal optical acuity and stage 3 hypertensive retinopathy. On physical examination, an extremely low body weight in relation to his height was noted $(49 \mathrm{~kg}, 180 \mathrm{~cm}$, respectively, $\left.\mathrm{BMI}=15.1 \mathrm{~kg} / \mathrm{m}^{2}\right)$. The examination of external genitalia revealed poor pubic hair development (Tanner stage 4) and a small penile size with an orthotopic urethral opening. A left testis of approximately 15 $\mathrm{ml}$ volume was palpable in the scrotum. There was no right testis palpable in the scrotum, whereas in the right external inguinal ring an ovular lesion of a diameter of less than $1 \mathrm{~cm}$ of hard consistency was found.

\section{Laboratory findings on admission}

Blood tests revealed end stage renal failure: creati- 
nine $9.7 \mathrm{mg} / \mathrm{dl}$, urea $240 \mathrm{mg} / \mathrm{dl}$, serum albumin concentration $2.8 \mathrm{~g} / \mathrm{dl}$ with total proteins $6.1 \mathrm{~g} / \mathrm{dl}$, potassium $4.7 \mathrm{meq} / \mathrm{l}$, sodium $139 \mathrm{meq} / \mathrm{l}$, calcium $8.2 \mathrm{mg} / \mathrm{dl}$ and phosphorus $8.9 \mathrm{mg} / \mathrm{dl}$. Protein excretion in 24-hours urine was $350 \mathrm{mg} / \mathrm{dl}$. Anaemia was revealed with anisocytosis, $(\mathrm{Hb}=9.4 \mathrm{~g} / \mathrm{dl}, \mathrm{Hct}=28.9 \%, \mathrm{MCH}=28.8 \mathrm{pg}$, $\mathrm{MCV}=88.7), \mathrm{ESR}=84 \mathrm{~mm}$ at $1 \mathrm{hr}, \mathrm{TIBC}=211 \mu \mathrm{gr} \%$ (lower normal $=225 \mu \mathrm{gr} \%$ ) and ferritine $=417.30 \mu \mathrm{g} / \mathrm{l}$ (upper normal reference value $=323 \mu \mathrm{g} / \mathrm{l}$ ).

Plasma sulfate dehydroepiandrosterone (S-DHEA) and 17-hydroxy-progesterone (17-OH-PRG) were normal (S-DHEA $=1719.5 \mathrm{ng} / \mathrm{ml}, 17-\mathrm{OH}-\mathrm{PRG}=1.9$ $\mathrm{ng} / \mathrm{ml})$. Plasma aldosterone and plasma renin activity in the upright posture were also normal $(192.7 \mathrm{pg} /$ $\mathrm{ml}, 8.4 \mu \mathrm{U} / \mathrm{ml}$, respectively). Urine metanephrines, normetanephrines and VMA excretion over a 24hour period were also normal $(84 \mu \mathrm{g} / \mathrm{dl}, 128 \mu \mathrm{g} / \mathrm{dl}$, $1.6 \mu \mathrm{g} / \mathrm{dl}$, respectively).

The investigation of the hypothalamic-pituitarytesticular axis demonstrated the presence of hypergonadotropic hypogonadism with low normal testosterone $(1.82 \mathrm{ng} / \mathrm{ml}$, reference values: $1.66-8.11 \mathrm{ng} / \mathrm{ml})$ and extremely elevated gonadotropins $(\mathrm{FSH}=148.7 \mathrm{mIU} /$ $\mathrm{ml}, \mathrm{LH}>250 \mathrm{mIU} / \mathrm{ml}$ ). Thyroid function was normal $\left(\mathrm{TSH}=1.15 \mathrm{mIU} / \mathrm{ml}, \mathrm{FT}_{3}=2.35 \mathrm{pg} / \mathrm{ml}, \mathrm{FT}_{4}=0.8 \mathrm{mg} /\right.$ dl, Anti-TG Abs: negative, Anti-TPO Abs: negative). Haematological, biochemical and endocrinological findings of the patient at hospital admission are shown in Table 1. Immunological tests (including ANA, cANCA, p-ANCA, ENA, Anti-ds-DNA), as well as auditive exams, were normal.

\section{DNA analysis}

Due to the concomitant occurrence of genitalia abnormalities and end stage renal failure, Frasier syndrome was suspected and a patient sample (peripheral blood) was referred to the Department of Medical Genetics, Athens University, for DNA analysis to investigate whether the patient had a mutation in the $W T 1$ gene. ${ }^{12}$

Genomic DNA was extracted from peripheral blood lymphocytes using the commercially available QIAmp DNA Blood Mini kit (Qiagen, GmBh, Hilden, Germany). Exons 8 and 9 of the WT1 gene, including $100 \mathrm{bp}$ of the flanking intronic sequences, were amplified by PCR. The primers employed were
Table 1. Haematological, biochemical and endocrinological findings of patient at admission

\begin{tabular}{|c|c|c|}
\hline & Patient & $\begin{array}{l}\text { Normal } \\
\text { values }\end{array}$ \\
\hline \multicolumn{3}{|l|}{ Haematology count } \\
\hline Haemoglobin (g/dl) & 9.4 & $12-18$ \\
\hline Haematocrit (\%) & 28.9 & $37-52$ \\
\hline Mean cell volume (fl) & 88.7 & $80-99$ \\
\hline Mean cell haemoglobin (pg) & 28.8 & $27-31$ \\
\hline $\operatorname{TIBC}(\mu \mathrm{g} \%)$ & 211 & $225-480$ \\
\hline Ferritin $(\mu \mathrm{g} / \mathrm{l})$ & 417.3 & $18.7-323$ \\
\hline \multicolumn{3}{|l|}{ Renal function } \\
\hline Creatinine (mg/dl) & 9.7 & $0.70-1.50$ \\
\hline Urea (mg/dl) & 240 & $10-55$ \\
\hline Serum albumin $(\mathrm{g} / \mathrm{dl})$ & 2.8 & $3.50-5.00$ \\
\hline Total protein $(\mathrm{g} / \mathrm{dl})$ & 6.11 & $6.00-8.40$ \\
\hline Potassium (meq/l) & 4.7 & $3.20-5.20$ \\
\hline Sodium (meq/l) & 1391 & $130-150$ \\
\hline Calcium (mg/dl) & 8.2 & $8.50-10.50$ \\
\hline Phosphorous (mg/dl) & 8.91 & $2.50-5.00$ \\
\hline 24hour urine protein $\mathrm{mg} / \mathrm{dl}$ ) & 350 & $<100$ \\
\hline \multicolumn{3}{|l|}{ Adrenal function } \\
\hline $\begin{array}{l}\text { Plasma sulphate dehydroepiandroste- } \\
\text { rone (S-DHEA) }(\mathrm{ng} / \mathrm{ml})\end{array}$ & 1719.5 & $800-5600$ \\
\hline $\begin{array}{l}\text { 17-hydroxy-progesterone } \\
(17-\mathrm{OH}-\mathrm{PRG})(\mathrm{ng} / \mathrm{ml})\end{array}$ & 1.9 & $0.5-2.9$ \\
\hline Metanephrines, 24-hour Urine $(\mu \mathrm{g} / \mathrm{dl})$ & 84 & $52-341$ \\
\hline $\begin{array}{l}\text { Normometanephrines, 24-hour Urine } \\
(\mu \mathrm{g} / \mathrm{dl})\end{array}$ & 128 & $88-444$ \\
\hline VMA, 24-hour Urine $(\mu \mathrm{g} / \mathrm{dl})$ & 1.6 & $1.8-6.7$ \\
\hline $\begin{array}{l}\text { Plasma renin activity, upright posture } \\
(\mu \mathrm{U} / \mathrm{ml})\end{array}$ & 8.4 & $5.0-50.0$ \\
\hline $\begin{array}{l}\text { Plasma aldosterone activity, upright } \\
\text { posture }(\mathrm{pg} / \mathrm{ml})\end{array}$ & 192.7 & $35.0-300.0$ \\
\hline \multicolumn{3}{|l|}{ Hypothalamic-pituitary-testicular axis } \\
\hline Testosterone (ng/ml) & 1.82 & $1.66-8.11$ \\
\hline FSH (mIU/ml) & 148.7 & $1.37-13.58$ \\
\hline $\mathrm{LH}(\mathrm{mIU} / \mathrm{ml})$ & $>250$ & $1.14-8.75$ \\
\hline TSH (mIU/ml) & 1.15 & $0.35-4.95$ \\
\hline FT3 (pg/ml) & 2.35 & $1.71-3.70$ \\
\hline FT4 (mg/dl) & 0.8 & $0.70-1.48$ \\
\hline
\end{tabular}

designed using software available in the public domain (Primer3 http://primer3.sourceforge.net) based on published information regarding the WT1 gene 
sequence (NCBI Reference Sequence: NG_009272.1). The oligonucleotide sequences of the forward and reverse primers are: exon 8 forward, $5^{\prime}$ cctttaatgagatccccttttcc3', exon 8 reverse, 5' 'ggggaaatgtggggtgtttcc3', exon 9 forward, $5^{\prime}$ cctcactgtgccacattgt $3^{\prime}$ and exon 9 reverse, 5'gcactattccttctctcaactgag3'. The PCR programme consisted of an initial denaturation step at $95^{\circ} \mathrm{C}$ for $15 \mathrm{~min}$ followed by 40 cycles, for exon 8 and 35 cycles, for exon 9 , of the following steps: $95^{\circ} \mathrm{C}-1$ min, $59^{\circ} \mathrm{C}-1 \mathrm{~min}$ and $60^{\circ} \mathrm{C}-1 \mathrm{~min}$ for exons 8 and 9 , respectively, $72^{\circ} \mathrm{C}-1 \mathrm{~min}$ and a final elongation step $72^{\circ} \mathrm{C}-8 \mathrm{~min}$. The amplicons were sequenced directly using the 7-Deaza-dGTP Cytm5/Cy5.5 Dye Primer Cycle Sequencing Kit (Bayer HealthCare, Leverkusen, Germany) sequencing kit in an OpenGene Visgen automated sequencer (Visible genetics, Ontario, Canada) and analyzed using the Unix Based Gene Objects 3.1 software. Following data analysis, a point mutation in intron 9 was identified (IVS9+4C > T).

\section{Clinical Progression}

Antihypertensive therapy was initiated and haemodialysis was started immediately via an arteriovenous fistula. Remarkably, concomitant with the completion of laboratory and genetic investigations the patient experienced a painful swelling of the left testis. At that time, a noticeable enlargement of the left testis, leading to a palpable mass of approximately $25 \mathrm{ml}$ volume with hard consistency, was observed. Ultrasound scan showed an enlargement of the left testis with diffuse echogenicity and microcalcifications as well as three hypoechogenic lesions of $21 \mathrm{~mm}, 10 \mathrm{~mm}$ and $14 \mathrm{~mm}$ diameter, respectively. Additionally, hydrocele was detected, whereas no ectopic right testis was found. Magnetic resonance imaging further confirmed the enlargement of the left testis with heterogeneity of the signal and disordered architecture, features implying a neoplasm. Additionally, in the right groin an oval shaped lesion measuring $17 \mathrm{~mm}$ in diameter with hypointensity in $\mathrm{T} 1$ sequence and intermediate intensity in $\mathrm{T} 2$ sequence was revealed. The presence of a right hypoplastic testis could not be excluded. Computed tomography confirmed that there were no pathological lymph nodes. The right kidney had a maximum diameter of $8 \mathrm{~cm}$ and the left kidney a maximum diameter of $7.1 \mathrm{~cm}$. Serum tumor markers are summarized in Table 2. The patient was submitted to bilateral testicular resection. Prosthetic testes
Table 2. Serum Tumor markers

\begin{tabular}{lcc}
\hline & Patient & Normal values \\
\hline$\beta$-HCG (mIU/L) & 23.39 & $<5$ \\
LDH (U/L) & 409 & $120-230$ \\
Alpha fetoprotein $(\mathrm{ng} / \mathrm{ml})$ & 0.85 & $<10$ \\
\hline
\end{tabular}

were implanted at the time of gonadectomy. Sperm preservation could not even be considered in the constellation of highly elevated FSH levels.

Histological analysis performed in the left testis revealed a germ cell tumor with morphological and immunohistochemical features consistent with a Sertoli cell tumor. The cells were arranged in tubules with solid areas, a characteristic that made the differentiation from seminoma challenging. Furthermore, the cells demonstrated clear or slightly eosinophilic cytoplasm, nuclei with atypia, mitosis and a great range of appearance as well as areas of necrosis, calcifications and elements of inflammation. Immunohistochemistry supported the discrimination between Sertoli cell tumor and seminoma. Indeed, the staining disclosed a strong positivity for vimentin in the cytoplasm as well as around the nuclei, positivity for cytokeratin and negativity for placental alkaline phosphatase and c-kit-1, which are all features characteristic of Sertoli cell tumor. Markers for neuroendocrine tumors were negative. Nuclei were positive for Ki 67 at a percentage higher than $40 \%$. The size of the neoplasm $(6.5 \mathrm{~cm})$, the increased number of mitotic figures as well as the atypia were all indicative of a malignant progress. The tumor was surrounded by an atrophic testis with hyalinized structures and hyperplastic Leydig cells. In the hypoplastic right testis, a gonadoblastoma measuring $0.5 \mathrm{~cm}$ in diameter was identified. Subsequently, the patient received adjuvant chemotherapy with Bleomycin, Etoposide and Cisplatin (Platinol) (BEP), with the prospect of continuing with androgen replacement therapy after the completion of chemotherapy.

\section{DISCUSSION}

Gonad and kidney development depends on the appropriate expression of the $W T 1$ gene, located on chromosome 11p13. Mutations at the intron 9 donor splice site of WT1 lead to a modification of the relative 
amounts of the $+\mathrm{KTS} /$-KTS WT1 protein isoforms and lead to the expression of Frasier syndrome. ${ }^{13}$

In FS, five different mutations have been reported to date at the intron 9 donor splice site: $\mathrm{c} \cdot 1228+2$ $\mathrm{T}>\mathrm{C}, \mathrm{c} .1228+4 \mathrm{C}>\mathrm{T}, \mathrm{c} .1228+5 \mathrm{G}>\mathrm{A}, \mathrm{c} .1228+5$ $\mathrm{G}>\mathrm{T}$ and $\mathrm{c} .1228+6 \mathrm{~T}>\mathrm{A}$. The mutation detected in our patient $(\mathrm{c} .1228+4 \mathrm{C}>\mathrm{T})$ is the most frequent mutation in FS, accounting for around $52 \%$ of reported cases. ${ }^{13,14}$ It is a hotspot mutation which arises from the potential to deaminate 5-methylcytocine at +4 and $+5 \mathrm{CpG}$ dinucleotide positions in intron 9.13,15 $\mathrm{CpG}$ dinucleotides are reported to have the highest rates of mutability for single-base-pair substitutions. ${ }^{16}$

In 46,XY patients, FS usually presents with complete gonadal dysgenesis, streak gonads and male to female sex reversal. ${ }^{17}$ The external female phenotype leads to female sex of rearing. To our knowledge, 46,XY phenotypically male FS patients are very rare, $, 15,18,19$ and amongst those genetically characterized only two have the same mutation as the patient in our report. One patient, an 8-year-old boy with IVS9+4C $>$ T mutation in the WT1 gene and male sex of rearing, reported by Denamur et al, ${ }^{18}$ presented proximal hypospadias, cryptorchidism, renal failure, Wilms' tumor and diaphragmatic hernia. Another study reported a 19-year-old male with IVS9+4C > T mutation in the WT1 gene, who had an unusual phenotype characterized by normal penile size, perineal hypospadias and end stage renal failure at the age of 19 years, extremely elevated gonadotropin levels, para-testicular leiomyoma, unilateral testicular germ cell tumor, bilateral gonadoblastoma and absence of gonadal dysgenesis. ${ }^{15}$ Other $W T 1$ mutations in three other FS patients with predominantly male genitalia (R390X, F392L and IVS9+5G-A) were reported from Japan. ${ }^{20,21}$ The phenotypic variability among different patients with the same mutation suggests that modifier genes and/or environmental factors may play a role in this variation. ${ }^{17}$

In our patient, the constellation of the IVS $9+$ $4 \mathrm{C}>\mathrm{T}$ mutation in the $W T 1$ gene, the XY disorders of sexual differentiation, the onset of nephropathy in the second decade of life and the development of gonadoblastoma as well as Sertoli cell tumor support the diagnosis of Frasier syndrome. Our patient had predominantly undervirilized male external genitalia that led to a male sex of rearing. He was born with bilateral cryptorchidism and scrotal hypospadias, but after surgical interventions at the age of 2 years he achieved male external genitalia and reportedly experienced normal sexual activity. At the age of 29 years he maintained low normal testosterone secretion with hypogonadism. This observation is in agreement with the patient described by Melo et al, who eventually developed bilateral gonadoblastoma and unilateral germ cell neoplasia. ${ }^{15}$ Our patient also developed gonadoblastoma in his cryptorchidic right testis and Sertoli cell tumor in his left testis, suggesting that the latter was preceded by gonadoblastoma, as the presence of gonadoblastoma in the right hypoplastic testis increases the risk for a new primary gonadoblastoma in the left testis, which could be a precursor lesion for the Sertoli cell tumor. ${ }^{22,23}$ However, this hypothesis cannot be confirmed. It is possible that gonadoblastoma is a result of the presence of dysgenic gonads or of differences in the stage at which gonadal development is arrested in Frasier syndrome and Danys-Drash syndrome. ${ }^{24}$

Sertoli cell tumors have a prevalence ranging from 0.4 to $1.5 \%$ of testicular malignancies in adults and up to $4 \%$ in children. ${ }^{17,25}$ Gomez-García et al reported a phenotypic male with FS and heterozygous WT1 mutation IVS9+5 G>A who, after prophylactic orchidectomy at the age of 19 years, showed arrest in spermatogenesis, intratubular germ cell neoplasia of unclassified type (ITGCN) and Leydig cell dysfunction. ${ }^{25}$ These data support a role of $W T 1+K T S$ in terminal Sertoli cell differentiation and maintenance and also confirmed for the first time in humans that critical levels of $S R Y$ and $S O X 9$ are also required for normal Sertoli cell differentiation and subsequent normal spermatogenesis. Ultimately, decreased expression of $W T 1+K T S, S R Y$ and $S O X 9$ may result in malignant transformation of germ cells.

Frasier syndrome and Denys-Drash syndrome are considered to be a continuum, since the two diseases are not always distinct, representing two ends of a spectrum of disorders caused by alteration in the WT1 gene..$^{15,26}$ In support of the continuum hypothesis are other reports of FS in a few patients with male ambiguous external genitalia, ${ }^{15,18,20,21}$ and also the development of Wilms' tumor in one case. ${ }^{27}$ Within the clinical follow-up, the risk of Wilms' tumor 
in such patients should also be evaluated, although a recent article provided substantial clarification as to the risk of developing Wilms' tumor in WT1 positive patients. ${ }^{28}$ According to Chernin et al, patients with WT1 missense or nonsense mutations have a high risk of developing Wilms' tumor, whereas patients with splice site mutations have a very low risk. ${ }^{28}$ Despite these findings, bilateral nephrectomy and kidney transplantation is under consideration in our patient. However, the progression of his gonadal neoplasms will play a determinant role in any treatment decision.

Our report presents a very rare case which illustrates the natural course of FS due to follow-up failure over many years. Furthermore, the present case adds new data to the spectrum of Frasier syndrome phenotypes associated with IVS9+4 C $>\mathrm{T}$ point mutations by including one more case of male ambiguous genitalia and also the co-existence of the rare Sertoli cell tumor with gonadoblastoma, a feature that further expands the phenotype variation of $W T$ mutations. It is emphasized that the early clinical recognition and molecular identification of the syndrome and removal of the dysgenetic gonads is of utmost importance since the syndrome is associated with a high risk of gonadal malignancy.

\section{DECLARATION OF INTEREST AND FUNDING}

Declaration of interest: All authors declare that there is no conflict of interest that could be perceived as prejudicing the impartiality of the research supported.

Funding: This work did not receive any specific grant from any funding agency in the public, commercial or not-for-profit sector.

\section{REFERENCES}

1. Frasier SD, Bashore RA, Mosier HD, 1964 Gonadoblastoma associated with pure gonadal dysgenesis in monozygous twins. J Pediatr 64: 740-745.

2. Moorthy AV, Chesney RW, Lubinsky M, 1987 Chronic renal failure and XY gonadal dysgenesis: Frasier syndrome - a commentary on reported cases. Am J Med Genet 3: 297-302.

3. Jeanpierre C, Denamur E, Henry I, et al, 1998 Identification of constitutional WT1 mutations in patients with isolated diffuse mesangial sclerosis and analysis of genotype/phenotype correlations by use of a computerized mutation database. Am J Hum Genet 62: 824-833.

4. Royer-Pokora B, Beier M, Henzler M, 2004 Twenty-four new cases of WT1 germline mutations and review of the literature: genotype/phenotype correlations for Wilms' tumor development. Am J Med Genet 127A: 249-257.

5. Saylam K, Simon P, 2003 WT1 gene mutation responsible for male sex reversal and renal failure: the Frasier syndrome. Eur J Obstet Gynecol Reprod Biol 110: 111-113.

6. Scharnhorst V, van der Eb AJ, Jochemsen AG, 2001 WT1 proteins: functions in growth and differentiation. Gene 273: 141-161.

7. Rauscher FJ 3rd, Morris JF, Tournay OE, et al, 1990 Binding of the Wilms' tumor locus zinc finger protein to the EGR-1 consensus sequence. Science 250: 1259-1262.

8. Wang ZY, Qiu QQ, Deuel TF, 1993 The Wilms' tumor gene product WT1 activates or suppresses transcription through separate functional domains. J Biol Chem 268: 9172-9175.

9. Haber DA, Sohn RL, Buckler AJ, et al, 1991 Alternative splicing and genomic structure of the Wilms' tumor gene WT1. Proc Nat Acad Sciences USA 88: 9618-9622.

10. Barbaux S, Niaudet P, Gubler MC, et al, 1997 Donor splice site mutations in WT1 are responsible for Frasier syndrome. Nat Genet 17: 467-470.

11. Fallat ME \& Donahoe PK, 2006 Intersex genetic anomalies with malignant potential Curr Opin Pediatr 18: 305-311.

12. Megremis S, Mitsioni A, Fylaktou I, et al, 2011 Broad and unexpected phenotypic expression in Greek children with steroid-resistant nephrotic syndrome due to mutations in the Wilms' tumor 1 (WT1) gene. Eur J Pediatr 170:1529-34. Epub ahead of print, Apr 16

13. Klamt B, Koziell A, Poulat F, et al, 1998 Frasier syndrome is caused by defective alternative splicing of WT1 leading to an altered ratio of WT1 _ _ KTS splice isoforms. Hum Molec Genet 7: 709-714.

14. Chan WK, To KF, But WM, et al, 2006 Frasier syndrome: a rare cause of delayed puberty. Hong Kong Med J 12: 225-227.

15. Melo KF, Martin RM, Costa EM, 2002 An unusual phenotype of Frasier syndrome due to IVS9+4C $>\mathrm{T}$ mutation in the WT1 gene: Predominantly male ambiguous genitalia and absence of gonadal dysgenesis. J Clin Endocrinol \& Metabol 87: 2500-2505.

16. Cooper DN and Youssoufian H, 1988 The CpG dinucleotide and human genetic disease. Hum Genet: 78: 151-155.

17. Schumacher V, Gueler B, Looijenga LH, et al, 2008 Characteristics of testicular dysgenesis syndrome and decreased expression of SRY and SOX9 in Frasier syndrome. Molec Reprod Devel 75: 1484-1494.

18. Denamur E, Bocquet N, Baudouin V, et al, 2000 WT1 splice-site mutations are rarely associated with primary steroid-resistant focal and segmental glomerulosclerosis. Nat Kidney Int 57: 1868-1872.

19. Auber F, Jeanpierre C, Denamur E, et al, 2009 Manage- 
ment of Wilms tumors in Drash and Frasier syndromes. Pediatr Blood \& Cancer 52: 55-59.

20. Kohsaka T, Tagawa M, Takekoshi Y, et al, 1999 Exon 9 mutations in the WT1 gene, without influencing KTS splice isoforms, are also responsible for Frasier syndrome. Hum Mut 14: 466-470.

21. Tajima T, Sasaki S, Tanaka Y, et al, 2003 46,XY phenotypic male with focal segmental glomerulosclerosis caused by theWT1 splice site mutation. Horm Res Pediatr 60: 302-305.

22. Lee EK, Holzbeierlein JM, 2009 Management of the contralateral testicle in patients with unilateral testicular cancer. World J Urol 27: 421-426.

23. Looijenga LH, Hersmus R, Oosterhuis JW, Cools M, Drop SL, Wolffenbuttel KP, 2007 Tumor risk in disorders of sex development (DSD). Best Pract Res Clin Endocrinol Metab 21: 480-495.

24. Koziel A, Charmandari E, Hindmarsh PC, et al, 2000
Frasier syndrome, part of the Denys Drash continuum or simply a WT1 gene associated disorder of intersex and nephropathy? Clin Endocrinol 52: 519-524.

25. Gomez-García I, Romero Molina M, López-García Moreno A, et al, 2010 Sertoli cell tumor, a rare testicular tumor, our experience and review of the literature. Arch Espanol Urol 63: 392-395.

26. Koziell AB \& Grundy R, 1999 Frasier and Denys-Drash syndromes: different disorders or part of a spectrum. Arch Dis Childhood 81: 365-369.

27. Barbosa AS, Hadjiathanasiou CG, Theodoridis C, et al, 1999 The same mutation affecting the splicing of WT1 gene is present on Frasier syndrome patients with or without Wilms' tumor. Hum Mut 13: 146-153.

28. Chernin G, Vega-Warner V, Schoeb DS, et al, Members of the GPN Study Group, 2010 Genotype/phenotype correlation in nephrotic syndrome caused by WT1 mutations. Clin J Am Soc Nephrol 5: 1655-1662. 